\title{
CORDOVIL, Daniela (Org.). Religião, gênero e poder: estudos amazônicos. São Paulo: Fonte Editorial, 2015. 206 p.
}

Hermes de Sousa Veras ${ }^{\star}$

*Universidade Federal do Rio Grande do Sul - Porto Alegre, RS, Brasil Doutorando em Antropologia Social hermesociais@gmail.com 
Li boa parte dessa coletânea nos ônibus, transitando pela Grande Belém. Certo dia, um vendedor de trufas, que subira no coletivo para vendê-las, olhou para a capa e me disse que não tinha nenhuma religião, pois ela seria a responsável por todos os males do mundo. Gostaria de ter tido tempo de lhe indicar a leitura da presente obra, que tem a importância de reunir pesquisas, preliminares e concluídas, sobre religião na Amazônia. Os autores e autoras dos textos foram todos alunos do Programa de Pós-Graduação em Ciências da Religião da Universidade do Estado do Pará (Uepa). A leitura, certamente, transformaria sua percepção monolítica do religioso.

Produzido sob a égide das ciências da religião, carrega diversos métodos e perspectivas (inter)disciplinares. A ênfase na relação gênero/poder está concatenada aos estudos anteriores da antropóloga Maria Angélica Motta-Maués (1993). O livro faz exercício de paridade, dos dez autores(as), cinco são mulheres, pois a introdução é escrita pela organizadora da coletânea. Passo, agora, a comentar em sequência os nove capítulos da obra.

Alysson Antero insere o marabaixo como manifestação religiosa afro-amapaense, e o como atividade de forte presença feminina, assim como aponta a ambiguidade apresentada pela Igreja Católica em relação a essa expressão popular, entre a tolerância e a perseguição. Os marabaixos eram realizados no centro de Macapá, contudo, a partir do processo de urbanização do local, as comunidades negras foram expulsas para as periferias da cidade, além de outras regiões do interior do estado. O panorama apresentado pelo autor revela uma atividade de populações negras e de seus descendentes, com forte manifestação afro-católica, na qual as mulheres possuem posição centralizada no que se refere à manutenção criativa das tradições.

Maria Pereira aborda o fenômeno das irmandades religiosas, essas organizações leigas religiosas que permanentemente estavam entre o movimento do catolicismo popular e o controle eclesiástico. As irmandades funcionavam como associações de direitos e deveres; partindo do pagamento de uma anuidade, os irmãos "tinham direito à assistência médica e jurídica, socorro em momentos de crise financeira, ajuda para a compra da alforria em caso de escravos" (p. 32). Utilizando os escritos do historiador paraense Arthur Viana como material empírico, a autora analisa o papel das mulheres na Irmandade de São Raimundo, em que, apesar de ser liderada pelo mestre Leopoldino, e essa é a tese de Pereira, possuíam importância 
crucial na manutenção e funcionamento da irmandade, além de serem maioria na instituição.

Tayná Lima traz uns dos únicos textos que não têm no seu foco a realidade amazônica, mas sim na cultura afro-brasileira na Bahia dos anos de 1930. A proposta é construir uma análise intertextual entre as obras As cidades das mulheres, de Ruth Landes, e Mar morto, de Jorge Amado. A autora busca mostrar como as duas obras constroem imagens literárias e etnográficas das relações de gênero na cultura afro-brasileira baiana. A estratégia argumentativa de Lima é compreender como as obras de Jorge Amado e Ruth Landes, ao se inserirem em contextos periféricos, revelam potências quando conectadas. Jorge Amado teve sua obra classificada como como piegas, e Landes fora duramente criticada por intelectuais (homens), principalmente Melville Herskovits e Arthur Ramos. Segundo Lima, a recepção negativa das obras se deu pela escolha por temas ligados à sexualidade. A partir dessa marginalidade dupla, a autora constrói um panorama de diálogo entre as obras.

Lucielma Silva traz rico material etnográfico sobre o tambor de mina em Abaetetuba (PA), conversando com lideranças religiosas, especialmente femininas, e entidades. Seu foco são as relações de "gênero" e por consequência de "poder" constituídas nos mundos dos terreiros. Ao concentrar-se nas interdições rituais sofridas pelas mulheres quando estão menstruadas, Silva conversa com pessoas de santo e suas entidades a respeito desse empecilho, concluindo que a mulher - e aqui, dialogando com Mary Del Priore -, por expelir sangue todo mês, torna-se um ser marcado por essa experiência, ocasião que muda com o envelhecimento. Essa transformação é valorizada pelo caboclo Seu Corre Beirada, que disse para a autora: "Mulher que presta é aquela que é vivida" (p. 92).

Jefferson Baldez fez pesquisa etnográfica no Ilê Asé Odé Ofã Arô Nilé, terreiro zelado por Pai Mário Sigbonilé (in memoriam), localizado na região metropolitana de Belém. O autor estuda em paralelo a vida mundana da Pombagira Lindeuá e sua vida espiritual, quando se torna uma entidade de umbanda. Baldez descreve que as entidades pombagiras geralmente possuíram histórias de vida marcada pela violência doméstica e findadas pelo feminicídio. É dessas experiências vividas que a pombagira extrai o seu poder, tanto de aconselhamento de fiéis quanto de transgressão moral, transformando-se em poder mágico para realizar o "trabalho bruto" dentro da casa, além de buscar o dinheiro que a sustenta. Baldez conclui que a pombagira 
representa a resistência e força feminina, que, por serem mulheres que sofreram em vida, acabaram por se transformar em espíritos de força e luz, repletas de experiências, onde se imbricam "política, religião, magia e gênero" (p. 109).

Mayra Cavalcante descreve as relações entre a pajé Zeneida Lima e as pajelanças "tradicionais" e as espiritualidades ecológicas, constituindo uma nova face da pajelança, encabeçada por Zeneida. A pajé é reconhecida no meio intelectual por conta de seus livros sobre os encantados e os caruanas, além de ter sido popularizada pela Escola de Samba Beija-Flor, no carnaval de 1998. Cavalcante mostra como Zeneida possui boas relações com as pessoas de fora de Soure, município localizado no arquipélago do Marajó, na medida em que algumas pessoas ao redor a temem, como uma figura perigosa, despertando o imaginário da mulher perigosa e mágica. Embora haja estudos sobre as mulheres pajés, Cavalcante mostra o quanto essas mulheres sofrem sanções por se dedicarem a essa religião. Porém, isso não as impede de serem pajés. Nesse aspecto, Cavalcante mostra que a pajelança de Zeneida se configura mais como uma pajelança ecológica - no sentido de dialogar com esses novos paradigmas da natureza - enquanto a pajelança de outras mulheres se configuram como a "cabocla", estudada na antropologia desde Eduardo Galvão. A pajelança de Zeneida atravessa todas as outras, e fica claro em Cavalcante que uma nova pajelança está por vir.

Manoel Chagas, ainda nessa linha ecológica, traz a construção de uma identidade ecológica pelos praticantes do candomblé jeje-savalu em Belém, focando-se no discurso da sacerdotisa Gayaku Jokolosy. Basicamente, o artigo perpassa a constatação de que "sem natureza não tem religião". Chagas mostra como a categoria ecológica pode funcionar tanto como uma afirmação política dos afrorreligiosos, como forma de fazer alianças políticas, quanto como um discurso feito por fundamentalistas para acusar as religiões afro de "bárbaras", por conta da sacralização animal. Essa sacralização, para as pessoas do jeje-savalu, é uma forma de equilibrar o mundo humano com o cosmos, e seu respeito para com a "natureza" não seria a partir de uma ótica funcionalista, e, sim, como uma própria maneira de estar no mundo.

Já no artigo de Luis Teixeira, o enfoque é a construção da identidade política a partir de três sacerdotisas do candomblé angola em Belém, trazendo como a identidade angola é construída em contraste com o batuque, forma como as religiões afro eram chamadas em Belém, até mais ou menos a década de 
1970. Se iniciar no candomblé seria uma forma, para Teixeira, de construir uma identidade política mais africana, e assim ganhar um maior status na disputa do "campo religioso". No último capítulo, Tony Vilhena estuda os discursos do metodismo, vertente do protestantismo histórico, sobre a diversidade sexual, analisando a carta pastoral intitulada "Igreja e a questão do homossexualismo", publicada em 2000. Houve também uma reformulação dessa carta, em 2007, por conta do projeto de lei $\mathrm{n}^{\circ} 122 / 1996$. Portanto, Vilhena analisa esses dois documentos tentando articular as relações entre política, religião e diversidade sexual. Resumindo seu argumento, Vilhena considera que o metodismo tem um discurso próximo de outras vertentes religiosas cristãs: pretende acolher essas pessoas e inseri-las numa regeneração moral, caindo numa "homofobia cordial" (p. 191).

Ao término do livro, ficam imagens diversas das articulações entre política, gênero e religião, que certamente devem interessar pesquisadores(as), religiosos(as) e leigos(as), que se ocupam desses temas na Amazônia ou para além dela.

\section{Referência}

MOTTA-MAUÉS, M. A. “Trabalhadeiras” e“Camarados”: relação de gênero, simbolismo e ritualização numa comunidade amazônica. Belém: Centro de Filosofia e Ciências Humanas, 1993. 